\title{
Effective Altruism as Egyptian Gold for Christians
}

\author{
"This is my prayer: \\ that your love may abound more and more \\ in knowledge and depth of insight, \\ so that you may be able to discern \\ what is best." \\ (Philippians 1)
}

\begin{abstract}
Despite primarily emerging in secular circles, effective altruism is not merely compatible with Christianity but is of significant value to it. Its insights offer much support to Christians aiming at serving their neighbour well. The chapter characterises effective altruism by way of seven commitments. Not all of these commitments are embraced by Christianity to their maximal extent. But they all point in the right direction if we compare the actual practice of Christians with the ideal. Christians are called to be more altruistic, and their altruism should put more emphasis on effectively achieving good consequences. In particular, the impartially assessed welfare consequences for those in need should receive more attention. Such a focus would benefit from more careful belief formation about what works in line with the epistemic practices advocated by effective altruism. The article also mentions one tension between the underlying mindset of effective altruism and Christianity. While effective altruism is driven by the aim of intentionally taking responsibility for results into one's own hands, Christianity includes an affirmation of trustfully letting go of control.
\end{abstract}

\section{Introduction}

Effective altruism (EA) started out as a very secular movement. Its roots are among Bay Area rationalists, Oxford philosophers, and East Coast hedge fund managers - not circles known for a religious slant. $86 \%$ of the movement's members profess to be atheist, agnostic, or non-religious. ${ }^{1}$ This article makes the case that a large part of EA's message is not merely compatible with Christianity but even of significant importance to it.

In the tradition of accepting prophetic words from outside the community of the faithful - think of Balaam in the Old Testament or Westphal's suggestion that Christians make use of the critical questions asked by Marx, Nietzsche, and Freud ${ }^{2}$ - Christians should humbly take up many insights that EA has developed. At the very least they should examine them with an open mind on the basis of the attitude propagated in 1 Thess. 5:21: "Do

2 Westphal, Suspicion and Faith. 
not treat prophecies with contempt but test them all; hold on to what is good."

The African theologian Augustine of Hippo was particularly forceful in his endorsement of integrating elements from non-religious culture into the Christian faith. While I presented it as humbly taking up insights he relies on the imagery of plundering the Egyptians (Exod. 12:35-36):

"If the [pagans] have said things which are indeed true and are well accommodated to our faith, they should not be feared; rather, what they have said should be taken from them as from unjust possessors and converted to our use. Just as the Egyptians had not only idols and grave burdens which the people of Israel detested and avoided, so also they had vases and ornaments of gold and silver and clothing which the Israelites took with them secretly when they fled, as if to put them to a better use."3

Just like the escaping Israelites took the gold of the Egyptians with them and later had it available to build the sanctuary (Exod. 25), so Christians, too, can recognise secular ideas and "baptise" these ideas for their purposes. In the context of this article, these purposes include in particular loving their neighbour well.

The article is structured as follows. Section 2 characterises EA by way of seven commitments. Section 3 examines the core question by running through the commitments one by one: in what ways is EA a useful tool for Christians in living out their faith? Section 4 discusses a big-picture tension between EA and faith. Section 5 concludes and also briefly comments on the reverse question: is the Christian faith a helpful tool for practicing EA?

3 Augustine and D. W. Robertson, On Christian Doctrine, section 40.60. 


\section{Characterising Effective Altruism}

EA has been understood in a number of different ways. ${ }^{4}$ For the purpose of examining its usefulness to Christians, I characterise it by way of seven commitments typically exhibited by its adherents:

(1) Altruism. Effective altruists dedicate a significant amount of resources to benefiting others.

(2) Consequentialism. Effective altruists embrace an altruism that is much focused on outcomes. This focus contrasts with other features of the moral situation that might guide one's altruism such as good intentions, virtues, respect for rights, etc.

(3) Welfarism. Effective altruists focus much on one specific aspect of outcomes: the welfare of individuals. This includes in particular its blunter elements such as physical and mental wellbeing. This focus contrasts with other aspects of outcomes that might guide one's actions, such

4 Examples can be found in MacAskill, "Definition," 12-14, including his own definition:

"(i) the use of evidence and careful reasoning to work out how to maximise the good with a given unit of resources, tentatively understanding 'the good' in impartial welfarist terms, and

(ii) the use of the findings from (i) to try to improve the world."

My characterisation deviates from MacAskill's definition mainly for practical reasons: comparing EA to other sets of commitments (in my case: Christian commitments) makes it helpful to split it up into distinct elements.

In terms of substance, my characterisation primarily deviates from his definition by making altruism an integral part of EA. While I agree that one could hold commitments 2-7 regardless of one's level of altruism, it seems somewhat contrived to exclude altruism from the definition of a movement called effective altruism (on this, see also the helpful discussion in Berkey, "Philosophical Core," 103-106). First, altruism plays an important role in the motivation of most real live effective altruists. Secondly, some parts of the movement have explicitly been built around altruism and not merely around practicing altruism in a specific way (including the Giving What We Can pledge and the concept of earning to give). Thirdly, altruism is the most natural explanation for why anyone would be interested in pursuing commitments 2-7 (cf. the oddness mentioned in MacAskill and Pummer, "Effective Altruism," 4). I agree however that EA can be seen as a project to which one is committed rather than a normative claim one holds: while $70 \%$ of effective altruists in fact do identify with utilitarianism (Dullaghan, "EA Survey 2019 Series") one could exhibit the seven commitments, i.e. pursue the EA project, for non-moral reasons such as excitement, a quest for meaning in life, "compulsively" being drawn to altruism by our evolutionary heritage, or selfish reasons in terms of hedonically profiting from the commitments. 
as the value that relationships, knowledge, or dignity have apart from whether they make anyone better off. ${ }^{5}$

(4) Impartiality. Effective altruists embrace a very impartial form of altruism. Individuals do not count more or less merely due to their sex, geographical location, time of birth, species, etc.

(5) Effectiveness. ${ }^{6}$ Effective altruists focus much on maximising the ratio at which a given amount of resources yields good outcomes.

(6) Truthseeking. Effective altruists oppose thoughtlessness and put much effort into forming beliefs that track reality well, in particular beliefs about the ratio at which resources yield good outcomes.

(7) Rationalism. ${ }^{7}$ Effective altruists' method for forming beliefs that track reality well emphasises empirical evidence, science, Bayesian thinking, skepticism, open-mindedness, quantitative tools, forecasting research, awareness of cognitive biases, etc. rather than intuition, conventional wisdom, superstition, etc.

In order to see the forest for the trees, it helps to summarise these seven elements into three steps and to highlight the logic behind grouping these three steps into one social movement.

Step I: Effective altruists are do-gooders (commitment 1) whose concern for others takes a specific form: impartial, welfarist consequentialism (commitments 2-4).

5 This non-welfare value could either be impersonal value or it could be personal value in the sense that it makes individuals' lives better without making it better for them, i.e. without increasing their welfare (see Wall, "Perfectionism in Moral and Political Philosophy," section 1). Note that things such as knowledge, friendship, or dignity could additionally be valuable, first, as elements of welfare in objective list theories and, secondly, instrumentally valuable for promoting welfare according to any theory of welfare. Further, these things could be morally relevant apart from their value.

6 Many would consider "efficiency" or "cost-effectiveness" to be more accurate terminology. They would use "effectiveness" more specifically for how much of a good outcome is achieved (rather than for how much of it is achieved per unit of resources). Unfortunately, this convention for a more precise use of language seems not to be followed widely.

7 It is hard to capture the eclectic bundle of views that make up the typical effective altruist's epistemology in a single word. The Centre for Effective Altruism captures it by the expression "evidence and careful reasoning". In order to be more specific but still broad, I crudely use the label "rationalism" in reference to the rationalist community, including the Center for Applied Rationality, as one paradigmatic exemplification of the endorsed style of thinking. This is admittedly a source of confusion since rationalism has many further meanings in other contexts (including as an opposite to empiricism). 
Step II: Consequentialism implies that one should focus on effectiveness (commitment 5).

Step III: The focus on effectiveness implies that one should focus on carefully assessing which efforts yield the best outcomes and this is best done by relying on a "rationalist" style of thinking (commitments 6 and 7).

None of these seven commitments need be pure or maximal. ${ }^{8}$ Rather, the lives of effective altruists are shaped by these commitments to a greater or lesser extent. ${ }^{9}$ Many people outside the movement embrace combinations of these commitments as well. Hence, EA could be reproached for lacking novelty. In response to this worry it should first be noted that even if EA lacked novelty it would not thereby automatically be irrelevant: the value of EA could be seen in publicising how the developments of the last, say, three decades in terms of the growth of technology, data, scientific understanding, and wealth have radically increased the impact of attending to the seven commitments compared to the previous history of humanity. But, in fact, EA is novel in at least three ways anyhow. First, EA is often more radical about the seven commitments than others. For example, while EA is not unique in emphasising that effectiveness matters, it stands out in emphasising just how much it matters. The best ways of benefiting others are often not just a bit better than average ways but by orders of magnitude better. ${ }^{10}$ Secondly, EA has been more forceful in teasing out underappreciated implications of the seven commitments. For example, EA is fairly unique in highlighting and exploring impartiality between people living in the present and the far future. Another example: EA points out that a commitment to effectiveness does not merely imply careful attention to prioritising between different interventions within a cause area but also between cause areas. There are few other cause-neutral movements united

8 Cf. MacAskill and Pummer, "Effective Altruism," 4.

9 Since adherents of the movement often emphasise different subsets of the seven commitments, different understandings of EA can sometimes look as if they were connected by family resemblance rather than by a core of individually necessary and jointly sufficient conditions (cf. Moss, "Maximising Altruism," 4).

10 See Caviola et al., "Donors Vastly Underestimate." 
by such an extremely general goal as doing the most good. ${ }^{11}$ Thirdly, EA has brought this combination of messages to new audiences. While some of the seven commitments taken on their own are thoroughly familiar to professional philanthropists, scientists, philosophers, business people, animal activists, policymakers, etc. bundling the seven commitments together as a common agenda for donors, activists, and voters is something new.

\section{Effective Altruism as a Plug-In for Christians}

I now examine whether EA helps Christians to practice their faith better. In other words: if Christians use a broadly rationalist epistemology in order to carefully assess which measures most effectively improve the welfare of all beings impartially considered, and if they put much resources into improving this welfare, does this make them live out their faith more fully? Or, more broadly: are the insights, the practices, and the style of the movement that sprung up around these seven commitments a helpful tool for Christians? In the words of Prov. 27:17: is EA an iron that sharps the iron of faith? Answering these questions includes - but is not limited to the minimal test of whether the seven commitments are compatible with the doctrines of Christianity.

\section{(a) Altruism}

When it comes to emphasising concern for others, EA preaches to the converted in addressing Christians. The call to care for the widow, the orphan, the stranger, and the poor is a constant chorus from the Mosaic law to the Psalms, the prophets, the gospels, and the epistles. This has often remained a theory in the history of Christianity but time and again it has also been

11 There is a distinctive challenge for EA movement building with respect to the first and second point, i.e. with respect to being radical about the seven commitments and teasing out underappreciated implications. The EA movement would already be an interesting and valuable movement if it were, say, twice as radical as the broad population about these commitments and if it teased out a small number of underappreciated implications. However, the EA movement is also interesting if it is ten times more radical and teased out utterly unfamiliar implications. How far should EA take its own ideas? The challenge is that the movement becomes overly heterogeneous if it groups those who are only at some distance from the broad population - which might well include quite some Christians in the movement - together into one movement with those who are at much further distance (though in the same direction) from the broad population. 
put into practice. Many social reforms and charitable interventions have ultimately been driven by Christian conviction even if these motivational roots were not visible at the surface. One of the signature features of Giving What We Can - donating at least $10 \%$ of one's income - is a common reference point for giving among believers, going back to the Old Testament concept of tithing. ${ }^{12}$ Even if only a minority lives up to the $10 \%$ benchmark, religious people give away a larger fraction of their income than secular people do. ${ }^{13}$ Thus, as far as the generosity message is concerned, Christianity can mostly profit from EA by finding new momentum through an ally. It is of course an ally that does not come out of nowhere but whose intuitions have been in many ways shaped by centuries of Christian concern for the poor and marginalised. The earliest builders of utilitarian theory were even explicitly Christian in their motivation.

EA is an ally not only in terms of endorsing altruism but also in terms of normalising or even celebrating altruism, including in its demanding forms. Rather than coyly acting for the benefit of others in secret out of fear of deviating from social norms, both Christianity and EA are blunt about viewing altruism as a key part of a life well-lived. The only difference is that the worry about character corruption of public giving looms larger in Christianity. ${ }^{14}$

Some Christians might worry about the specific terminology of altruism. The term was popularised by Auguste Comte who had a firmly non-Christian agenda. Nothing hinges on the term, however. It is simply a useful concept for effective altruists - and also for Christians - due to its extreme generality which distinguishes it from other concepts such as love or justice. According to one understanding of the concept, any behaviour that benefits others is altruistic, regardless of its motives. ${ }^{15}$ This suits both Christianity

12 This is despite the fact that the rules for the various tithes in the Old Testament are difficult to understand and that tithing is hardly mentioned in the New Testament at all. When it comes to giving, the New Testament mentions various ideas - including giving half of one's possessions (Luke 19:8), selling all one's possessions (Mark 10:21), having everything in common (Acts 2:45), giving according to one's means (Acts 11:29; 1 Cor. 16:2), or giving beyond one's means (2 Cor. 8:3).

13 See for example Austin, Giving to Religion. Even those who are critical of there being a positive link between religion and generosity acknowledge that it is clearly the mainstream view (cf. Sablosky, "Does Religion Foster Generosity?"). A recent literature review even suggested that religion "most often positively relates with giving to outgroup and secular organizations." (Yasin et al., "How Does Religion." Emphasis mine).

14 Jesus' injunction not to announce with trumpets when giving to the needy is discussed specifically with relation to EA in a blogpost by Synowiec, "Should we sound."

15 Kraut, "Altruism." 
and EA as they want to make space for motivational roots of altruism that are not directly about wanting to benefit others or give them what they are owed - such as excitement, selfishness, personal character development, or an urge to express gratitude for overflowing blessings by passing them on.

\section{(b) Consequentialism}

Christian ethics features strong consequentialist elements. Making good things happen is part of the Christian vision - obviously so. Camosy observes:

"[M] any traditional Christians display a broadly consequentialist structure to their moral reasoning. Singer wants to produce the consequence of maximal preference satisfaction, whereas many Christians (especially Thomists) understand the moral life teleologically - with the proximate goal, some say, of the flourishing of all creation (with a special emphasis on vulnerable persons), and an ultimate goal of achieving union with God." 16

The much more difficult question is how dominant we should take the consequentialist element of Christian ethics to be. There is significant terminological confusion - which leads to substantive confusion - in the debate about consequentialism. The idea of a moral view which pays no attention to consequences at all is a strawman. The debate is rather about the question of whether we should pay attention to nothing but consequences (consequentialism) or, in case considerations other than consequences - such as rights, rules, virtues, or intentions - matter as well (non-consequentialism), how much attention these other considerations should receive.

I welcome the explicit acknowledgement of leading effective altruists that EA does not imply a commitment to consequentialism in the sense that only consequences matter. MacAskill and Pummer even define EA as "the project of using evidence and reason to try to find out how to do the most good, and on this basis trying to do the most good, without violating constraints." 17 In this crude form, the principle is not spelled out enough to do any serious work. (Possibly, the lack of nuance reveals that this qualifying clause is more of a deferentially accommodating - rather than fully authentic - attempt at

16 Camosy, "Engaging with Peter Singer," 69.

17 MacAskill and Pummer, "Effective Altruism," 5. The emphasis is mine. Another representative example is Todd and MacAskill's statement on the 80,000 hours website that their default position - which allows for exceptions - is not to "take a career for the greater good if that career directly causes significant harm." (Todd and MacAskill, "Is it ever okay.") 
ecumenism?) Unless constraints were understood such that the acceptable exceptions are already baked into the constraint ("Don't lie unless $\mathrm{x}, \mathrm{y}$, or $\mathrm{z}$ is the case"), this crude wording rules out all the interesting cases where we should violate constraints in order to promote good results. It is hardly a controversial position that we should sometimes do so, both for the deontological sensibilities of common sense as well as for Christians. While the Bible obviously gives center stage to moral constraints, there are numerous instances where it is distinctively non-pharisaical about breaking these rules. An example is David eating the consecrated bread (1 Sam. 21) - an occurrence which is approvingly cited by Jesus in Luke 6 where the reason for breaking the recognised rules notably consists in down-to-earth benefits such as eating, healing, and saving lives. And it is not just ritual rules. In Exod. 1 the Egyptian midwives are rewarded by God for helping the Israelites even if doing so necessitated lying to the Pharaoh.

Leaving these preliminary remarks on consequentialism aside, the question then is: is the effective altruist call to focus much on consequences a helpful exhortation for Christians? The answer is: yes, at least as long as the call is limited. The call is useful but it should stop short of asking Christians to embrace full-blown consequentialism. Let me discuss the yes first and then turn to its limits. My argument for the yes is indirect: I portray consequentialism's main competitor - deontology - as a temptation. There are three ways in which humans are seduced to follow an excessively deontological stance and to give too little emphasis to consequences.

First, there is the temptation to seek an easy route to feeling assured of being on the morally right side by following simple rules. In Luke 11:42 Jesus exclaims "Woe to you Pharisees, because you give God a tenth of your mint, rue and all other kinds of garden herbs, but you neglect justice and the love of God." He does not dismiss rules but shifts the focus of his audience by telling them to "be generous to the poor, and everything will be clean for you." This is reminiscent of a parallel skepticism in the Old Testament towards focusing on ritual laws, for example in Mic. 6:6-8: "Shall I come to Him with burnt offerings, with yearling calves? (...) He has told you, O man, what is good; and what does the Lord require of you but to do justice, to love kindness, and to walk humbly with your God?" Following clear rules allows for peace of mind about having clean hands. In comparison, the open-ended task of taking responsibility for every way in which one's choices impact others is harder to bear.

Secondly, there is the temptation to dial down demandingness by relying on an excessively deontological morality. Admittedly, deontology can also be more demanding than consequentialism because it demands respect 
for rights and rules even if doing so comes at great cost to oneself and others. But the bigger theme is how deontology can be less demanding than consequentialism because it makes space for supererogation. According to deontological morality, we do not have the duty to go for the morally best option. This allows for pegging the dividing line between duty and supererogation at a non-ambitious level. The temptation to exploit this is particularly strong given that deontology's complexity allows for hiding our motivation behind elaborate distinctions. Jesus criticises the complacency involved in merely jumping through deontological hoops in the Sermon on the Mount (Matt. 5:21-22): "You have heard that it was said to the people long ago, 'You shall not murder, and anyone who murders will be subject to judgment.' But I tell you that anyone who is angry with a brother or sister will be subject to judgment." In Matt. 19:8 Jesus presents the possibility for divorce explicitly as an accommodation of the human struggle with a more demanding morality. A particularly relevant example of implausibly toning down morality's demands by exploiting deontological distinctions happens in the case of positive duties. These duties - to actively do something rather than merely refrain from doing something - are often seen as significantly weaker than negative duties in a deontological perspective. In contrast, the Bible mentions positive and negative duties naturally together (cf. Prov. 14:31 and Luke 19:8). Charles Camosy - who remarks that Jesus rarely speaks of hell except in the context of duties to the poor - notes that in the famous passage of Matt. 25 the sins that separate the hell-bound from the heaven-bound are all sins of omission. ${ }^{18}$ Key figures in church history equated the failure to share one's wealth with theft. And regular penance in many churches explicitly involves confession of both acts and omissions. The consequentialist call to take responsibility for all the consequences our actions and omissions is a very helpful corrective to the natural biases of sinful creatures who are tempted to hide selfishness in the complex edifices of deontological theories and to categorise too many actions as supererogatory nice-to-haves.

Thirdly, a further temptation of deontology is vengefulness. As consequentialism is forward-looking it only sees a point in retribution if this creates positive incentives for the future. Christianity, too, is skeptical of vengefulness: dealing with wrongful behaviour is God's business (and it can include forgiving it). While the Christian skepticism towards retribution has different roots than consequentialism's, Christians can still value the

18 Camosy, "Engaging with Peter Singer," 72, 74. 
"letting the past be past" attitude as a helpful crutch to counteract our sinfully vengeful nature. ${ }^{19}$

My claim is thus that the consequentialist elements of any, including a Christian morality, are in danger of being crowded out by an overblown attention to deontological considerations. The temptation to do so exists because deontology allows us a simpler way to ascertain that we have paid our dues, makes space for toning down demandingness through motivated reasoning, and gives fuel to our feelings of vengefulness. ${ }^{20}$

There is a further - and key - reason why Christians typically give too little emphasis to consequentialist considerations in their practical reasoning. This reason has nothing to do with deep moral theory but rather with changing empirical circumstances. Most sensible deontological theories are stakes-sensitive: rights and rules can be overridden if the stakes in terms of axiological value - are high enough (and this is so even if deontological theories struggle to spell out the precise conditions under which such overriding is justifiable). The stakes of many decisions have massively risen in the past few years and decades. Due to the growth of technology, wealth, and data, the resources and knowledge of ordinary people allow for much bigger impact than they used to. We should expect consequences to override deontological considerations much more often than in the past. Thus, regardless of whether our overall moral theory gives much or little space to consequentialist considerations, these considerations have become practically much more relevant. EA opens our eyes to this implication of almost any sensible moral theory.

Thus, EA is helpful in pushing Christians to be more consequentialist. However, Christians can only go so far in embracing consequentialism. Its scope must be limited in at least two ways for Christians.

First and straightforwardly, a number of key non-consequentialist considerations are forcefully present in scripture. The decalogue features a number of rules for specific kinds of actions rather than merely injunctions to promote certain values. The call to forgive only makes sense under the assumption that we can wrong each other whereas consequentialism struggles to explain how actions cannot just be wrong but wrong someone. The Bible

19 This is especially relevant in applying EA to the political realm where a lot of conventional action seems optimised for confronting the bad guys rather than serving their victims.

20 Of course, deontology is not the only competitor to consequentialism. In the common philosophical classification, virtue ethics is the most prominent third option. Here, too, there are temptations, in particular to shape the focus on one's own character development in a self-centered way. 
exhibits much respect for the choices of agents even when these decisions wreak havoc. Paul says in 1. Cor. 13 that if we gave all we possess to the poor but did not have love, something essential would be missing. The list is endless. ${ }^{21}$ First impressions could of course be deceptive and it might, for all we know, be possible to uncover a consequentialist rationale behind all the superficially non-consequentialist considerations. This would not be hard for some instances of non-consequentialism in scripture. For example, the command to honour the Sabbath or not to kill could reasonably well be consequentialised. However, the number and extent of non-consequentialist stances makes it a steep uphill battle to fully consequentialise the Bible.

Secondly, even if true morality were ultimately consequentialist, it is not clear that humanity is tasked with promoting any good consequence or whether we have particular responsibility for only a subset of all good consequences. It could be argued that there is a sort of division of labour between the Heavens and the Earth: God gives less responsibility to humans for certain areas of life since he has particular plans for these areas and since he has great epistemic and motivational advantages over humans. One possible example is this: there is a clear scriptural mandate addressed to humans to relieve suffering and oppression but a less clear mandate to bring about good effects over and above this threshold. The latter - renewing all things and bringing about blissful flourishing of the whole cosmos - might be disproportionately God's responsibility. Another example that is highly relevant to $\mathrm{EA}$ is longtermism: affecting the long-term trajectory of the planet such that it matches a predestined arch of history might be distinctly God's business.

21 In numerous discussions about Christianity and EA, I have repeatedly encountered the alabaster jar scene and the parable of the lost sheep as two of the most paradigmatic cases of a non-consequentialist vision in the Bible. However, these passages do not seem like clear instances at all. First, the alabaster jar scene: the fact that the disciples speak out - and that they address Jesus rather than the woman - indicates that their past experience with Jesus lets them expect approval from Jesus. And, in fact according to Mark 14:7, Jesus' reply does not sound like a fundamental repudiation of their general stance: "The poor you will always have with you, and you can help them anytime you want." His rebuke seems more focused on the exceptional situation at stake. The lost sheep, too, is rather more supportive than critical of a consequentialist stance. Obviously, the parable's message is not that the plight of the ninety-nine is inconsequential in the decision whether to save the one sheep. The message is rather in line with the consequentialist insistence that the numbers count - that every single individual matters. More is better: even if ninety-nine are in safety, the hundredth sheep matters, too. 
Population ethics deserves a specific mention in the limitations on consequentialism. Population ethics matters much for the prominent focus on existential risks among effective altruists: if humanity were to go extinct prematurely, we would miss out on all the good consequences that could have been experienced by the "containers" that will never be born. However, population ethics is a domain that might fall under either of the two above-mentioned limitations on consequentialism: first, it might be an area where consequentialism is the wrong approach for Christians or, secondly, it might be an area where consequentialism is the right approach but applying it is too overwhelming a task for earthlings. The first might be the case if we take total consequentialism to be the most obvious extension of consequentialism to the domain of population size. Scripture does not positively seem to endorse a total consequentialist stance. To the extent that it breaks its silence on the topic at all, the injunction from Gen. 1:28 to fill the earth seems to rather be of a satisficing nature. The optimal number of individual humans could well depend on the reason God had for creating humanity in the first place - where this reason is at least not obviously the maximisation of good consequences. The second might gain plausibility if we consider the fact that population ethics is one of the most perplexing areas of ethics. ${ }^{22}$ It might surpass human understanding and thus be left to God. ${ }^{23}$

It is useful to note that limiting consequentialism in these two ways can make a genuine practical difference in some cases. For example, if Christians are committed to a right to subsistence, fulfilling the basic needs of the few can take precedence over fulfilling non-basic needs of the many even if good consequences were maximised by fulfilling the latter rather than the former. Or, it could be a correct course of action radically to reduce the number of animals who will ever be born in order to increase respect for the rights of those animals who will actually be born. Or, if respecting the free choices of individuals is key, the success of Christian missionary efforts should be measured - if at all - by the extent to which the good news is offered rather than accepted. However, all these examples should not hide the fact that all too often Christian limitations on consequentialism are surprisingly

22 Cf. Arrhenius, "The Impossibility of a Satisfactory Population Ethics."

23 Similarly, the epistemic challenges in comparing the goodness of salvation to the goodness of food on the table in the here and now might be insurmountable for human reasoning. Thus, if consequentialism were the correct approach to evangelism, it might be up to God to communicate practical guidelines for this domain to humans rather than humans getting lost in infinite ethics. On this, see also Liberman, "Effective Altruism and Christianity," section 4. 
irrelevant on a practical level. Feeding the hungry, developing interventions against depression, reducing factory farming is important - and often similarly so - on both a Christian and a full-blown consequentialist stance.

\section{(c) Welfarism}

Given that Christians should focus much - but not as exclusively as consequentialists - on bringing about good consequences, the question comes up: what are the good consequences in question? Many effective altruists believe that the amount of welfare in a state of affairs exhaustively determines its goodness. In contrast, many Christians question such an exclusive focus on welfare. Instead, they insist that goods such as worship of God, relationships, knowledge, etc. matter not merely as potential constituents of - or contributors to - welfare, i.e. someone's life going well. Given that it would take more space than available to evaluate whether welfare is the only intrinsic value, I focus on the more limited question whether Christians should give more attention to welfare than they typically do. Even this limited question is difficult to assess, however. I therefore limit myself even further to suggesting that there are at least some elements of welfare which are in danger of being downplayed by Christians. These are the down-to-earth elements of welfare such as food or happiness.

Crisp observes that "[w]ell-being obviously plays a central role in any moral theory." 24 This is certainly true for Christianity. In particular, some simple and straightforward aspects of welfare here on earth play a central role in a Christian vision, too. The Bible gives much space to the theme of avoiding hunger, healing illness, and lamenting depressive states of mind. (And not just in the negative sense of avoiding a deficit: the Exodus from Egypt, for example, is not merely a journey out of oppression; it is also a journey into a land of milk and honey). Psalms do not just focus on worshipping God but also dwell on the gladness that accompanies worshipping God. On the very final pages of the Bible the new Jerusalem is characterised by God wiping every tear from our eyes and the absence of pain (Rev. 21:4). There is something profoundly odd with Christians - possibly as a counterreaction to the superficial visions of human purpose that some of their secular contemporaries or the adherents of the prosperity gospel espouse - dismissing a concern with the more earthly elements of welfare as too materialistic. If the key importance of human lives going well gets forgotten in overly moralising approaches to faith, and if welfare's blunter 
elements such as enough and nice food get forgotten in overly spiritualising approaches to faith, effective altruism can serve as a corrective. ${ }^{25}$

There is also a practical reason why focusing on welfare, in particular on its blunter elements, helps Christians in living up to their faith's commitments. MacAskill notes that "given the current state of the world and our incredible opportunity to benefit others, the best ways of promoting welfarist value are broadly the same as the best ways of promoting the good." 26 Welfare is often a decent proxy for the good in general, and the blunter elements of welfare are often a decent proxy for welfare in general (plus: extremely crude measures such as Quality-Adjusted Life Years (QALYs) or GDP per capita are often decent proxies for the blunter elements of welfare). This is the case not least because the blunter elements of welfare contribute to welfare in general and also to non-welfare aspects of the good. For example, reducing the risk of hunger, illness, and poverty often has the effect that people can acquire knowledge, get empowered, can stand up for their rights and dignity, can express themselves and exercise their autonomy, and can foster their relationships rather than having to seek work far away from family and friends. The great benefit of focusing on material aspects such as food, health, and income is that they are more easily measurable than the harder-to-grasp elements of welfare and the good in general. Even if aiming at such crude proxy measures introduces some distortions, these distortions might be worth the increased tractability. And there are psychological benefits, too: focusing on measurable factors has a disciplining effect by providing accountability. It confronts us with the truth about the results of our efforts in a way that focusing on the ultimate values will always miss out on. We often forget how difficult it is directly to aim at deeper objectives. Many effective altruists who give center stage to the blunt objective of increasing QALYs do not mistake this crude measure for the real thing. They are fully aware that aiming at a limited measure of welfare is only a practical tool in the service of a grander aim. If, for a pilot in foggy weather who steers a plane with malfunctioning equipment, the

25 Note also Ryan Miller's comments regarding hedonism in one of the few existing pieces at the intersection of faith and EA. He argues that opposition to hedonism "is a strange line of criticism for Thomists, since Aquinas professes that happiness is the last end of man" (Miller, "80,000 Hours for the Common Good.") It should be noted, however, that Aquinas espouses a non-reductive view of happiness according to which happiness is found in God rather than in pleasure.

26 MacAskill, “The Definition of Effective Altruism," 18. 
only alternative to operating on the basis of a crude proxy is flying blindly, then limited vision is better than no vision at all. ${ }^{27}$

Summing up: EA's emphasis on welfare, including its more down-toearth elements, is a healthy reminder for Christians who are in danger of downplaying these elements of the good. Equally importantly, focusing on these blunter elements can be a perfectly helpful tool for better achieving the ultimate vision of the good; this is so on account of the tractability and accountability that the measurability of these simple goals provides.

\section{(d) Impartiality}

Effective altruists embrace an altruism that is very impartial: others count equally regardless of sex, geographical location, time of birth, species, etc. Should this effective altruist commitment to impartiality be welcomed by Christians?

There is a major challenge in assessing whether someone's commitments are overly partial or not sufficiently partial. The reason is that partiality is a surprisingly difficult concept in two ways. First, while impartiality plays a key role in any convincing moral stance it is an open question among which units one ought to be impartial. Should all interests count equally or should all individuals count equally? And if all individuals count equally, should all human individuals, all sentient individuals, or all living beings count equally - or should even natural systems or inanimate objects be included in the circle of units who ought to be treated equally? While the answer to this question makes all the difference, the mere commitment to impartiality does not settle it. Effective altruists who draw their intellectual inspiration from Peter Singer are often not very transparent about the fact that they have impartiality between interests or pleasure in mind rather than impartiality between individuals. This can be interpreted as partiality for those with weighty interests or much potential for pleasure. For example, if humans experience a lot more pleasure than insects then saving a human life is more important than saving an insect's life. The second reason why partiality is hard to spot is that a commitment to

27 To be sure: measurability, tractability, and accountability are no values per se if EA lives up to its ultimate commitments. They can lead us astray, for example if we choose more measurable interventions on account of the nice feeling of being able to vividly seeing impact, if tractable solutions bias us towards low-risk-low-impact solutions, or if accountability biases us towards short-term solutions given that future generations cannot hold us to account. 
impartiality at the fundamental level of one's theory often leads to actions and institutions that look partial at the surface. There are a host of reasons for this. One is the very practical reason of division of labour: in order to organise life efficiently, some assume larger than average responsibility for particular people even if there is agreement that ultimately everyone deserves equal attention. Another practical reason is epistemic: we often know the preferences and circumstances of close people better than those of people far away. There are also more subtle reasons. For example, personal relationships are a significant component of a good life, and humans might be psychologically hardwired in a way that makes it difficult to cultivate relationships without exhibiting some partiality within those relationships (such as instinctively saving one's spouse from a fire ahead of other people without second thoughts).

Given these difficulties, I propose two tests for assessing whether Christians should welcome EA's strong call for impartiality as a prophetic voice that pushes them in the right direction. The first test asks whether the Bible and other sources of authority in Christianity concur or disagree with the effective altruist vision of impartiality, and the second test asks whether we have reason to assume that there are psychological drives that tempt us towards excessive partiality.

The first test does not yield a clear answer. On the one hand, there are obviously warnings of partiality in the Bible. For example, the Bible and Christian tradition speak out against tribalism by emphasising kindness towards strangers; Jesus and Paul are both critical of family commitments standing in the way of commitment to God's mission (Luke 14:26; 1. Cor. 7:8); and the New Testament universalises the faith that developed in the Old Testament (Gal. 3:28). It is particularly noteworthy that the parable of the Good Samaritan - a key passage on love of neighbour and the eponym in modern English for helping strangers - is not about the question whether one should love one's neighbour. That one should do so is the premise of the parable. The parable itself is about the question of whom to see as one's neighbour. By contrasting how the Samaritan - a person from a different culture than Jesus' primary audience - chose to act as a neighbour to the wounded man, Jesus seems forcefully to speak out against limiting one's responsibility towards the near and dear.

However, there is no simple and clear endorsement of impartiality in the Bible. ${ }^{28}$ There are, for example, hints of a weak priority for sisters and brothers in faith (cf. Gal. 6:10). The weakness of this priority can

28 See also Liberman, "Effective Altruism and Christianity," section 2.3. 
be seen in various instances. When Jesus was approached by a Canaanite woman in need, he responds by emphasising the primacy of his mission to the children of Israel. This emphasis, however, is quickly trumped by admiration for the woman's faith (Matt. 15:21-28). Ryan Miller notes that Aquinas, "grants that closeness to the giver of alms is a circumstance yielding a certain claim on care, [but] he nonetheless insists that it be a lesser criterion than the extent of need." ${ }^{9}$ Similarly, John Wesley in his famous and in many ways effective altruist sermon on the use of money proposes a model which amounts to closeness acting as a tie-breaker in case various people's basic needs aren't satisfied. ${ }^{30}$ However, even if this looks like an explicit endorsement of partiality it would still be a radical departure from real-world practice given that benefiting close ones over and above the level of basic needs would not be justified as long as the basic needs of anonymous strangers are not yet satisfied. Perhaps the clearest endorsement of partiality in the Bible can be found with respect to animals. Jesus explicitly says that one human is worth more than many sparrows (Matt. 10:31). The special role of humans is also evidenced by the Bible's more extensive focus on the ethical treatment of humans compared to the ethical treatment of animals. Of course, this should in no way be seen as a biblical endorsement of the mistreatment of animals in today's world. After all, in saying that humans matter more than sparrows Jesus simultaneously says that sparrows do matter. God the father cares for them, which is also evidenced by a number of Psalms mentioning God's provision for animals (e.g. Ps. 136:25) and by the fact that the covenant after the flood includes the animals (Gen. 9:9-10). ${ }^{31}$ Note also that a Christian perspective could in principle overtake even Peter Singer in how it lifts up animals: if every creature is valuable in God's eyes, those creatures without or with only extremely little sentience, such as oysters, ${ }^{32}$ could have a higher moral status in a Christian perspective than in a utilitarian perspective. Also, Christianity could join forces with utilitarianism in shifting attention from livestock animals to wild animals, on account of the fact that the foundational mandate to care for creation (Gen. 1:28) is not limited to a negative duty not to mistreat farm animals. ${ }^{33}$

29 Miller, "80,000 Hours for the Common Good."

30 Wesley, "The Use of Money," section III.3.

31 Further, today's mass exploitation of animals cannot be endorsed from a Christian perspective since it has multiple negative effects on humans, too, most notably via its environmental consequences.

32 And, for that matter, also unborn humans.

33 Cf. Crummett, "Human Dominion and Wild Animal Suffering." 
These gesturing comments make clear that Christianity does not feature as straightforward a stance on impartiality as the utilitarianism that informs many effective altruists. Thus, if anything, the first test shows that the Christian ideal of impartiality is somewhat weaker and, in complex ways, of a different shape than the ideal of utilitarianism-inspired effective altruists. However, the question of the correct ideal regarding impartiality seems surprisingly irrelevant. I venture the claim that there are sufficient temptations for partiality in life such that almost anyone among us should adopt the working assumption of not being impartial enough, regardless of whether the benchmark for impartiality is utilitarianism or Christian ethics. Thus, all of us should move in the direction of more impartiality (even if different ideals disagree on how much more we should move in which precise direction). These temptations for overdoing partiality have various roots. One is the tribalism that evolution has ingrained in us. Another important root is the selfish motivation for being nice to those who are close-by and therefore have the power to be nice to us as well - a point which is highlighted by Jesus himself (Matt 5:46). A still further root is the fact that our social norms and intuitions have developed in a context where there was much less potential to expand one's concern to people far away in time and space. Factors such as these lead one to assume that common sense expectations about impartiality in combination with the possibilities of a 21 st century world exhibit a much too parochial focus. Thus, EA's emphasis on impartiality pulls us in the right direction.

Summing up: when it comes to impartiality, the practically relevant question in assessing EA's helpfulness to Christians is not the extent of overlap of the impartiality ideal in theory. The practically relevant point is that Christians can assume their natural and sinful instincts to be overly partial - and thus welcome EA's enthusiasm and radicalism on impartiality as a forceful tool pulling in the right direction.

\section{(e) Effectiveness}

Effective altruists focus much on maximising the ratio at which the resources they use for benefiting others yield good outcomes. This is a direct implication of consequentialism since getting more out of the resources one puts to the service of others is one of two ways of bringing about better outcomes for others (where the other simply consists in giving more resources). 
Effectiveness is by far the biggest reason why EA is relevant to Christians. The goal of loving our neighbours includes, as a key part, the goal of promoting their welfare. And EA has shown that we can increase the benefits for our neighbours to a much larger extent by translating our efforts more effectively into benefits than by increasing our efforts. While we can typically increase our efforts by a factor of, say, two or three, we can sometimes increase the factor by which our efforts are translated into results by a factor of ten, a hundred, or even more. ${ }^{34}$ Forgoing these massive wins is wrong on consequentialist grounds. And to the extent that any plausible moral view gives much attention to consequences, EA helps us to better live up to this aspect of our overall moral view. On a more virtue ethical style of reasoning, it is wasteful; and the sheer fact of unnecessarily forgoing benefits which could be had without increasing our effort is revealing of a lack of compassion. If the benefits in question are necessary for fulfilling rights, forgoing them might well also be wrong on deontological grounds. ${ }^{35}$ Note that none of this is a philosophically or theologically deep insight. EA has not discovered a new aspect of the fundamental structure of morality. Rather, it merely opens our eyes to an important implication of the benevolence that is part of any plausible morality. The relevance of carefully attending to effectiveness is the forest that critics of EA should see instead of the trees. Alas, the critics often note that effectiveness is a consequentialist concern which immediately triggers their worry of excessive consequentialism. It is a real pity that the conversation gets hung up on old debates about consequentialism in general, or even utilitarianism. ${ }^{36}$

34 See Caviola et al., "Donors Vastly Underestimate."

35 Some people are critical of such a "utilitarianism of rights" where we have greater reason to fulfil more rights than fulfilling less rights. In contrast, they insist on rights as constraints on the space within which maximization should happen. However, if in this fallen world humanity does not fulfil all the rights they should, I find it plausible that at least with respect to the shortfall, one should take a consequentialist approach: minimising the extent to which one fails to do what one minimally ought to do as a matter of rights-based duties.

36 McMahan ("Philosophical Critiques of Effective Altruism") laments this too, particularly in light of the fact that both Singer's ("Famine, Affluence, and Morality") earliest arguments as well as Unger's (Living High and Letting Die) more systematic arguments for demanding duties of the kind that effective altruists promote rely on widely held intuitions and are not dependent on utilitarianism. One of the very few academic publications that mention EA in the context of faith unfortunately also falls into the trap of putting EA too quickly in the context of old debates about utilitarianism (Gregory, "Charity, Justice, and the Ethics of Humanitarianism," 8-10). 
If focusing on effectiveness is such a crucial instrument for responding in love to the cries of this earth and its inhabitants, one might wonder why effectiveness does not play a more prominent role in the Bible. One explanation is, of course, that it is a practical insight. The relevance of the practical insight depends on empirical circumstances. For almost all of human history it was comparatively unimportant. But its significance has skyrocketed over the past few decades due to the improved availability of data as well as scientific and technological developments. Another response is to claim that there are in fact two biblical "proof texts." The most obvious is the parable of the shrewd manager (Luke 16:1-13). It is a difficult parable to interpret but the upshot that seems most natural is summed up in Jesus' concluding sigh that, roughly speaking, the faithful should be as shrewd in pursuing good goals as evil people are in pursuing bad goals. The second is the parable of the talents where Jesus rebukes the servant who played it safe and made sure not to lose anything. The version conveyed in Luke 19:1127 is particularly noteworthy: the two good servants achieved different returns and the one who maxed out on the opportunities was given extra praise and extra responsibility. Aside from these two texts, there are some further passages one could interpret as endorsing an effectiveness mindset. An example is Ephesians 5:15-16: "See then that ye walk circumspectly, not as fools, but as wise, redeeming the time, because the days are evil."

But whether or not one finds direct scriptural evidence for the importance of effectiveness, the indirect evidence is overwhelming: love of neighbour combined with the novel situation of massive and detectable differences in effectiveness between different cause areas and interventions in the twenty-first century point to effectiveness as a key moral imperative for Christians of our time.

\section{(f) Truthseeking}

Effective altruists put much effort into improving their beliefs, in particular beliefs about which actions are most effective. This praise of careful thinking is certainly in line with the Bible. Most clearly this is the case for the passages in praise of wisdom. It also chimes well with Christianity's high regard for truth and its trust in a certain intelligibility of the workings of this world. One should, however, be careful not to ascribe to EA any appreciation of wisdom as intrinsically virtuous. ${ }^{37}$ For EA, the emphasis

37 Cf. Synowiec, "Temperance and prudence as virtues of an effective altruist," who discusses EA in the context of the virtue of prudence. 
on reason is justified by its instrumental benefits: taking a step back to carefully examine the situation is supported as a means to improve the world, and not because such thoughtfulness is virtuous in itself. While some might lament that such an instrumental justification of wisdom does not go far enough, it does allay a worry that some Christians might have about EA: an idolisation of science, reason, and nerd culture. While such idolisation might sporadically happen in reality, it is not inherent to the underlying logic of the EA project - on the contrary. If certain unscientific epistemic practices were to achieve epistemic or non-epistemic benefits say, if astrology-based counselling were to provably help people find orientation in life or mentally recover from crises - effective altruists would seem to have no principled objection to it.

A fact which is often overlooked is that the use of reason as an instrument of love appears in one of the most central passages of the Bible. In Matthew 22:37-39 Jesus identifies the commandments to love God with all one's heart, all one's soul, and all one's mind and the commandment to likewise! - love one's neighbour as oneself as the core that binds together the Law and the Prophets. It is important to note, first, that in a Hebrew mindset the heart is pictured as the center of human thinking and planning rather than as the seat of emotions and, secondly, that the reference to the mind was added by Jesus himself to the wording of the quoted Old Testament passages. Thus, there is a genuine appreciation of reason's role in one of the most famous biblical calls to love. ${ }^{38}$

\section{(g) Rationalism}

Effective altruists celebrate specific methods and mindsets for arriving at beliefs that reliably track reality such as open-mindedness, quantitative tools, and empirical evidence. To the extent that these methods and mindsets are helpful tools for finding the truth, they must of course be endorsed from a Christian perspective, and there is not much to be added on this matter. Christians do recognise certain additional instruments for accessing the truth, such as direct instruction by the Spirit or authoritative teaching of the church. Also, given God's action in the world, Christians might view the world as somewhat less predictable than secular EAs. Thus, there are inevitably some differences. However, in practice, for most topics of relevance to the EA project, these differences are negligible. Christians often

38 This is laid out with respect to EA in a blogpost by Stefan Höschele, "Love with all your mind." 
miss out on the tremendous practical benefits of these intellectual tools out of fear that they are embedded in a naturalistic ideology. If Christians were more pragmatic in this respect and took all these tools such as, say, simplified quantifications to be mere instruments that helpfully discipline the search for impactful ways of serving their sisters and brothers in need, so much would be gained. Much would already be gained if they trusted scientific tools as much when it comes to promoting their neighbour's welfare as when it comes to pursuing their own welfare, say in their own health or consumption decisions.

Let me sum up the gist of section 3. The dialectical situation is such that many theorists are wary of EA on the basis of their opposition to pure utilitarianism. Given that EA does not necessitate a commitment to utilitarianism, they miss out on just how powerful a tool it is for serving the needy. For Christians, there are certainly some elements of EA that they must not endorse as fully as some of its paradigmatic adherents. However, in almost all cases EA pulls Christians in the right direction relative to the status quo: for Christians to love their neighbours better, they should be more altruistic, more consequentialist, more welfarist, more impartial, more effective, more focused on truthseeking, and their epistemology more rationalist.

\section{A Big Picture Tension: Letting Go of Control}

There is an overarching mindset behind the EA project: "Be deliberate about the shape of your altruism. Rather than going with the intuitive flow and rather than taking current forms of expressing altruism as given, step outside the ingrained habits and embrace intentionality in choosing how to serve others. You are in charge of actively optimising effects across any cause areas by deploying all available resources. Don't embrace an attitude of non-judgmental acceptance towards reality - change it. Don't let things happen. If humanity doesn't take responsibility, no one will."39

In contrast, Christianity allows us - and demands of us - not to take control of everything we can affect. We are to let go of the hold we seek to have on everything and put things into God's hands. The mindset is one of surrender to God's mysterious and powerful presence in this world. Rather than acting like an engineer who fine-tunes every button on a big, complex machine we ought to espouse the mindset of children trusting

39 There is no necessary link between this mindset and the specific shape of altruism that EA has embraced. Rather the overarching mindset could lead to other upshots. 
their parents to lead them well. ${ }^{40}$ While EA encourages us to take control of things, Christianity encourages us to let go of control - and this tension has increased in recent years in lockstep with the increase of humanity's powers to control its fate.

Biblical examples include the following:

- In Judg. 7, God asks Gideon to deliberately go to war with 300 men even though 32,000 would have been available. Gideon is to deliberately refrain from making use of all available resources.

- In Matt 6, Jesus encourages us not to worry about tomorrow. The illustrations he gives are birds who do not invest for the future and the completely passive lilies.

- In Ps. 127, we are encouraged to take a good night's rest rather than labour late. This encouragement is based on the claim that "unless the Lord builds the house, the builders labour in vain."

- In Ps. 131, the writer approvingly compares himself to a child who says "I do not concern myself with great matters or things too wonderful for me." This is similar to the line from Isaiah 55: "For my thoughts are not your thoughts, neither are your ways my ways."

- James 4 encourages a particular mindset: "Now listen, you who say, 'Today or tomorrow we will go to this or that city, spend a year there, carry on business and make money' (...) Instead, you ought to say, 'If it is the Lord's will, we will live and do this or that." This is similar to Ps. 94:11 which says: "The Lord knows all human plans; he knows that they are futile."

- In Exod. 14, the Israelites are discouraged from an active stance in the face of an opposing army. Rather they are to observe the Lord taking action: "Stand firm and you will see the deliverance the Lord will bring you today (...) The Lord will fight for you; you need only to be still."

- Mark 4 provides one of the clearest instances: "This is what the kingdom of God is like. A man scatters seed on the ground. Night and day, whether he sleeps or gets up, the seed sprouts and grows, though he does not know how. All by itself the soil produces grain - first the stalk, then the head, then the full kernel in the head."

40 The key theme of letting go of ambition, control, and optimization is not unique to Christianity. It is particularly present in the mystical strands of various faiths as well as movements closely adjacent to spiritual paths, such as mindfulness or Alcoholics Anonymous. 
- More generally, there is also the fact that God repeatedly chose unimportant and weak agents for doing his work - and they often achieved his purposes in mysterious, roundabout, and seemingly wasteful ways.

There are a couple of straightforward rationales for this emphasis on letting divine providence take its course rather than incessantly planning pro-active interventions. First, God has epistemic advantages. Humans need to remember their limitations and the concomitant benefits of listening to the one who has a much better overview of this complex universe. Secondly, some domains which humans can affect are simply not part of their portfolio. Rather, they are God's domain of sovereignty. Determining the lifespan of humanity or selecting specific humans for salvation might be cases in point. Thirdly, a lot of these examples can be interpreted to serve the mental health of overambitious do-gooders. Such a concern with self-care is in fact a point of overlap with EA. In contrast to other moral views, EA does not place an emphasis on good motivation and high sacrifice. Given that impact rather than effort matters, and given that not overburdening oneself with responsibility can serve impact in the long run, EA agrees with the upshots of a number of these passages. Fourthly, in a lot of these examples the point seems to be about character development, in particular practicing trust and humility. For example, Gideon was to rely on a small number of soldiers so as to avoid the temptation of boasting. Framing it as character development might cast this fourth point too superficially, though, and too much on the ethical level. The Bible reports on the experience of having to die off so as to receive life (for example in John $12: 24-25)$ and surrendering completely might be part and parcel of this overall spiritual practice of losing oneself in order to find God.

These four considerations are speculative. And even if they provide some rationale for refraining from exercising control where it would be possible to do so, significant mystery remains. The paradoxical nature of the Christian stance of surrendering control when action would seem possible and advisable is expressed in such sayings as "Pray as though everything depended on God; act as though everything depended on you" or Paul's words "For when I am weak, then I am strong" (2 Cor. 12:10).

The rationale for foregoing control is not our concern here anyway. The concern is the tension with EA's underlying mindset of not letting any chance go unused to affect the world for the good. While this tension is real, one should, however, not exaggerate its extent. This is so for two reasons. The first is that the Christian faith also, and utterly clearly, affirms initiative, action, planning, and the use of reason to pursue outcomes in a 
results-oriented way. If there is any tension with EA, this tension is already present within the Christian faith. The Christian faith's affirmation of a pro-active attitude towards shaping this world is limited, and it is embedded in an underlying trustful sense of complete dependency on God. To some extent the tension can be eased by going for the EA mindset in our actions and the Christian mindset in our attitudes. However, this only reduces the so-called paradox of surrender. If the Christian attitude of falling back on God's sovereign working in this universe is taken seriously, it must have some implications for our actions. There is a second reason for drastically limiting the tension. For most people in our fallen world, the alternative to EA - i.e. the alternative to a more controlling and deliberate approach to what one can affect - is typically not trust in God. Realistically, the alternative is typically thoughtlessly doing the first available good deeds on the doorstep and blindly continuing on well-trodden paths in one's charitable efforts. If EA encourages people to move from thoughtless forms of love to more intentional forms, this is at least a step forward - and this is so even if committing the efforts to God's wise providence were an even greater step forward. Even if a controlling attitude is spiritually problematic, it is at least an improvement over neither actively taking responsibility oneself nor actively placing this responsibility in God's hands.

\section{Conclusion}

An excerpt from Paul's prayer in Phil. 1:9-10 captures many of EA's ambitions: "This is my prayer: that your love may abound more and more in knowledge and depth of insight, so that you may be able to discern what is best." It expresses the longing for boldness in our love and the desire to use insight in order to go beyond merely doing good to doing the best. No wonder this chapter's examination of the various elements of EA arrived at the conclusion that they are useful in supporting the Christian endeavour of loving one's neighbour well.

The reversal of the question would be a relevant topic, too: to what extent is Christianity a better or worse soil than secularism for the EA project to flourish? While there is no space here to discuss this in depth, three points deserve a quick mention. First, Christianity provides a good home for justifying and motivating altruism compared to the more freefloating commitment in secular approaches. In addition to featuring firm and divinely endorsed moral commands, there are a number of motivations in Christianity that are not as easily available in a secular perspective, such 
as gratitude for the overflowing gifts one has received or a confidence that one does not have to look out for oneself since someone else is in charge of doing so. Secondly, and perhaps controversially, I submit that while Christianity might not necessarily provide a better home for the commitment to science than a secular context - after all, superstition and extremism have flourished in religious circles time and again - it might possibly provide a more stable home in the longer term. Secular approaches are exposed to risks of nihilism and relativism and such extreme risks to the commitment to science are alien to many strands of Christianity. Thirdly, many effective altruists are committed to an extremely demanding morality. While demandingness may not in itself decrease the plausibility of these approaches in the slightest, it does pose an existential problem: how can we personally come to terms with the all-but-guaranteed failure to live up to an extremely demanding morality? At the very center of Christianity there is the emphasis on grace in the face of overwhelming moral demands. Our future and our wellbeing are dissociated from our shortcomings. In addition to practical psychological help in dealing with an overwhelming world, this experience responds to the demandingness problem at an existential level.

Effective altruists might of course point out how Christianity also offers a worse basis for EA in certain respects. For example, as this chapter argued, Christianity exhibits a less than full commitment to some of the project's elements such as consequentialism or impartiality. However, this less than full commitment is practically not of much relevance. In real life, the bottleneck is usually insufficient and messy human motivation rather than somewhat diverging ideals which would only gain much relevance if our motivation were much increased. Thus, for both secular and Christian effective altruists, the call to be more altruistic, more consequentialist, more welfarist, more impartial, more focused on effectiveness, more careful in one's belief formation and more rationalist in doing so is a helpful corrective to their natural tendencies. It is not just a mildly helpful corrective but from the perspectives of the billions of victims of this brutally broken world - an incredibly important corrective. Thank God for the advent of effective altruism. ${ }^{41}$

41 I am grateful for the extensive and very thoughtful comments by Brian Green, Rochelle Harris, Vesa Hautala, Caleb Huffman, David Lawrence, David Moss, Stefan Riedener, as well as the participants of the workshop on "Religious Perspectives on Effective Altruism" in Fribourg in 2019 and the 2021 online workshop of the same title organised by Caleb Huffman. I am grateful for the many years of discussion in the Christians and Effective Altruism Facebook group founded by Andy Chrismer and the EA for Christians community that grew out of it. 


\section{References}

Arrhenius, Gustav. "The Impossibility of a Satisfactory Population Ethics." In Descriptive and Normative Approaches to Human Behavior, edited by Hans Colonius and Ehtibar Dzhafarov, 1-26. Singapore: World Scientific Publishing Company.

Augustine and D. W. Robertson. On Christian Doctrine. New York: BobbsMerrill, 1958.

Austin, Thad. Giving to Religion. Giving USA. 2017. https://givingusa.org/j ust-released-giving-usa-special-report-on-giving-to-religion/.

Berkey, Brian. "The Philosophical Core of Effective Altruism." Journal of Social Philosophy 52, no. 1 (2021): 92-113.

Camosy, Charles. "Engaging with Peter Singer." In God, the Good, and Utilitarianism: Perspectives on Peter Singer, edited by John Perry, 68-90. Cambridge: Cambridge University Press, 2014.

Caviola, Lucius, Stefan Schubert, Elliot Teperman, David Moss, Spencer Greenberg, and Faber, Nadira. "Donors Vastly Underestimate Differences in Charities' Effectiveness." Judgment and Decision Making 15, no. 4 (2020): 509-516.

Crisp, Roger. "Well-Being." In The Stanford Encyclopedia of Philosophy, edited by Edward N. Zalta (Winter 2021 Edition). https://plato.stanf ord.edu/archives/win2021/entries/well-being.

Crummett, Dustin. "Human Dominion and Wild Animal Suffering." Religious Studies 57, no. 4 (2021): 1-17.

Dullaghan, Neil. "EA Survey 2019 Series: Community Demographics \& Characteristics." Rethink Priorities. 5 December 2019. https://www.rethi nkpriorities.org/blog/2019/12/5/ea-survey-2019-series-community-demo graphics-amp-characteristics.

Gregory, Eric. "Charity, Justice, and the Ethics of Humanitarianism.” In Everyday Ethics, edited by Michael Lamb and Brian Williams, 81-102. Washington, DC: Georgetown University Press, 2019.

Höschele, Stefan. "Love with all your mind." A blog for the Effective Altruism for Christians community. 23 October 2019. https://eachdiscus sion.wordpress.com/2019/10/23/love-with-all-your-mind.

Kraut, Richard. "Altruism." In The Stanford Encyclopedia of Philosophy, edited by Edward N. Zalta (Fall 2020 edn.). https://plato.stanford.ed u/archives/fall2020/entries/altruism.

Liberman, Alida. "Effective Altruism and Christianity: Possibilities for Productive Collaboration." Essays in Philosophy 18, no.1 (2017): 6-29. 
MacAskill, William. Doing Good Better. How Effective Altruism Can Help You Make a Difference. New York: Penguin Random House, 2015.

MacAskill, William. "Effective Altruism: Introduction." Essays in Philosophy 18, no. 1 (2017): 1-5.

MacAskill, William. "The Definition of Effective Altruism." In Effective Altruism. Philosophical Issues, edited by Hilary Greaves and Theron Pummer, 10-28. Oxford: Oxford University Press, 2019.

MacAskill, William, and Theron Pummer. "Effective Altruism." In International Encyclopedia of Ethics, ed. by Hugh LaFollette, 2020.

MacMahan, Jeff. "Philosophical Critiques of Effective Altruism." The Philosopher's Magazine 73 (2016): 92-99.

Miller, Ryan. "80,000 Hours for the Common Good: A Thomistic Appraisal of Effective Altruism." Proceedings of the American Catholic Philosophical Association (forthcoming).

Moss, David. "Maximising Altruism and Effective Altruism: Mapping the Terrain.” (Unpublished Manuscript, 2016). https://www.academia.edu/3 4673134/Maximising_Altruism_and_Effective_Altruism_Mapping_the_ Terrain.

Sablosky, Roy. "Does Religion Foster Generosity?” The Social Science Journal 51, no. 4 (2014): 545-555.

Singer, Peter. "Famine, Affluence, and Morality." Philosophy and Public Affairs 1 (1972): 229-43.

Synowiec, Jakub. "Temperance and prudence as virtues of an effective altruist." Logos $i$ Ethos 54 (2020): 73-93.

Synowiec, Jakub. "Should we sound a trumpet when we give to the poor?" A blog for the Effective Altruism for Christians community. 17 March 2018. https://eachdiscussion.wordpress.com/2018/03/17/should-we-sou nd-a-trumpet-when-we-give-to-the-poor.

Todd, Benjamin and William MacAskill. "Is it ever okay to take a harmful job in order to do more good? An in-depth analysis." Accessed 24 November 2021. https://80000hours.org/articles/harmful-career/.

Unger, Peter. Living High and Letting Die: Our Illusion of Innocence. New York: Oxford University Press, 1996.

Wall, Steven. "Perfectionism in Moral and Political Philosophy." In The Stanford Encyclopedia of Philosophy, edited by Edward N. Zalta (Fall 2021 Edition). https://plato.stanford.edu/archives/fall2021/entries/perfectionis m-moral.

Wesley, John. “The Use of Money." Accessed 24 November 2021. https://w ww.whdl.org/use-money-sermon-50. 
Westphal, Merold. Suspicion and Faith: The Religious Uses of Modern Atheism. New York: Fordham University Press, 1998.

Yasin, Kidist Ibrie, Anita Graeser Adams, and David P. King. "How Does Religion Affect Giving to Outgroups and Secular Organizations? A Systematic Literature Review." Religions 11, no. 8 (2020): 405. 